RESEARCH ARTICLE

\title{
URGENCY OF WAQF LAND REGISTRATION IN THE CONTEXT OF INDONESIAN LAND REFORM
}

\author{
Saiful Anwar \\ Postgraduate Program, Faculty of Law, Universitas Negeri Semarang, Indonesia \\ $\bowtie$ saifull50lanwar@gmail.com
}

\section{CITED AS}

Anwar, S. (2020). Urgency of Waqf Land Registration in the Context of Indonesian Land Reform. Journal of Law and Legal Reform, 1(3), 479-492. DOI: https://doi.org/10.15294/jllr.vli3.36702

\begin{abstract}
Land registration ordered by Government through Law Number 41 Year 2004 about waqf aims to make society to be discipline in implementing of waqf practices. Beside the public order, the registration of waqf land has a positive urgency for waqf land. Either the urgency of waqf land registration normatively, sociologically, or juridically. However, the fact shows that the enforcement indications are still minimal. This fact is due to the lack of Nadzir and Wakif (who donates property) understanding about the urgency of waqf land registration. They assume that waqf land that has already recorded administratively by government institution has already registered. While the provisions of agrarian law (lands) are not the case. The interpretation of new land registration is listed in Article Paragraph 1 of Government Regulation Number 24 Year 1997 which requires legal force through the ratification of authority official registration, because it will be used as evidence data. The implementation of land registration will produce evidence sign of land called certificate.
\end{abstract}

Keywords: Urgency; Certification; Waqf; Land Certification 


\section{TABLE OF CONTENTS}

\begin{tabular}{|c|c|}
\hline ABSTRACT & 479 \\
\hline TABLE OF CONTENTS & 480 \\
\hline INTRODUCTION .... & 480 \\
\hline METHOD & 482 \\
\hline URGENCY OF WAQF LAND REGISTRATION $\ldots \ldots \ldots \ldots \ldots \ldots \ldots \ldots \ldots$ & 482 \\
\hline I. NORMATIVE URGENCY OF WAQF LAND REGISTRATION & 48 \\
\hline II. SOCIOLOGICAL URGENCY OF WAQF LAND REGISTRATION ... & 48 \\
\hline III. JURIDICAL URGENCY OF WAQF LAND REGISTRATION ........... & 488 \\
\hline 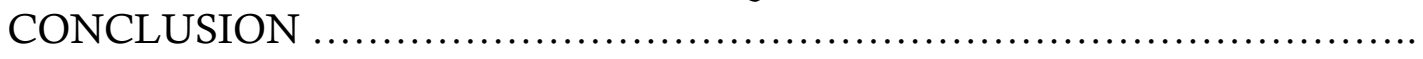 & 490 \\
\hline SUGGESTION & 491 \\
\hline REFERENCES & \\
\hline
\end{tabular}

\section{INTRODUCTION}

The existing of Law Number 41 Year 2004 about waqf and completed with Government Regulation Number 42 Year 2006 about the implementation of Law Number 41 of 2004 about waqf marks the management practices of Waqf develop quickly. It means that, in Indonesian, people interest in donating assets increases with time. According to the statistic from the Islamic Community Guidelines of the Ministry of Religion Republic Indonesia reached 353.646 with an area of 49.026 HA or equivalent to $490.260 .000 \mathrm{~m}^{2}$ (siwak.kemenag.go.id). This land spreads in various regions throughout Indonesia with different point and level with the highest position of Java Island. West Java occupies in the top position with 70.815 points, Central Java is in the second position with 96.331 points, and East Java with 64.016 points.

The emerging of Law Number 41 of 2004 about waqf basically used as community guideline or administrative basis on waqf management so that it is useful productively (Budiman, 2015: 16). The key role of waqf management not only put on Nazir and solid work team ability to maximize the waqf potential. However, administrative obedience as regulated in Law is the basic capital that must be implemented first (Hasmi, 1987: 19).

This condition can be interpreted that every waqf land management must be based on applicable regulations. However, in the reality, from the number of 353.646 , as already revealed by Indonesian Waqf Agency (BMI) there were 148.447 waqf land points have not certificate yet. It is because they do not register their waqf lands (siwak.kemenag.go.id). 
The majority of the general public is still confused in understanding the meaning of waqf land registration. According to him, if a plot of land has been recorded administratively by government institution, they assume that their land has already registered. While the provision of agrarian law (lands) is not in the case. The explanation of new land registration is contained in the Article 1 Paragraph 1 of Government Regulation Number 24 Year 1997. Implementing of land registration in modern society is a state task carried out by the Government for people's interest, in providing legal assurance in land sector. Some of its activities in the form of land physical data collection whose rights are registered, can be assigned to the private sector. But, to obtain the legal force, the results require the legalization of an authorized registration official, because it will be used as evidence data (Harsono, 2008: 72).

The implementation of land registration will produce land evidence called certificate. It is the realization of the objectives of the LoGA. The obligation to conduct that registration, principally charged to the government and its implementation carried out in stages, region by region based on consideration of the availability of the registration basic map (Sumardjono, 2001: 181).

There is an indication that land registration process in the Regional Leadership of Muhammadiyah Semarang has not all followed the provisions of Law Number 41 of 2004 about waqf and other Regulation of implementing about waqf. This can be seen from the lack of concerning by the Leadership of Muhammadiyah Semarang to manage and administer waqf lands, it means that Leadership of Muhammadiyah Semarang only accept people who come to donate, but Leadership of Muhammadiyah Semarang did not provide directives previously that should be done by people in order to give motivation to them to donate the land, including the procedure for registering waqf land. In addition, there is a lack of understanding of waqf managers (Nazhir) in managing waqf land.

That's fact can occur because some of people who do not know, understand, obey the provision regulation of waqf well. Public ignorance of a statutory regulation especially Law Number 41 Year 2004 about Waqf, may be caused by the luck of waqf land socialization to public.

Seeing this phenomenon concerning the waqf land which is not registered must be evaluated on how people can obey the applicable law. As in way not to complicate in administration matter. However, the question is, will the people obey or disobedient in obeying the applicable waqf Law? This condition must be answered by knowing in advance why the waqf land is not registered and how the legal implication for the waqf land itself. 
As intended that the purpose of recording waqf land so that the existence of waqf land can be protected and supervised from prohibited practices in Law. The Article 40 of Law about waqf states that waqf property that has already donated, it is prohibited used as assurance, confiscated, granted, sold, bequeathed, exchanged, and transferred in the form of other rights transfer.

\section{METHOD}

This research uses a qualitative research approach. Qualitative research is a research that focuses on the general principles which underline the manifestation of phenomenon in human life, or patterns of analysis of the socio-cultural by using culture and society concerned to obtain overview of the prevailing patterns. The basis of qualitative approach emphasizes the human behavior pattern, as seen from "frame of references" of the subjects themselves, so individual as central subject need to be understood and it is as a unit analysis and place them as part of the whole (Holistic) (Ashshofa, 2010: 21). While, the type of this research is juridical-sociological research. Juridical-sociological legal research is a research that examines law aspects and it is compared with social aspect or social phenomena in society. It is due to the law cannot be separated from social condition that exist in society (Wignjosoebroto, 2009:133). The focus includes discovering why the urgency of waqf land registration in Perspective of Law Number 40 of 2004 about waqf by taking a research location at Regional Leadership of Muhammadiyah Semarang. The main data source in qualitative research is data source that collected directly through respondents or informants including interview with the regional leadership of Muhammadiyah as Nazhir who manage the waqf land and waqif as the land giver to be donated. Data analysis techniques used is an interactive model that is conducted by means of data collection, data reduction, data presentation, and data verification (Miles dan Huberman on Rachman, 2012: 200-201).

\section{URGENCY OF WAQF LAND REGISTRATION}

Actually, the existing of the regulation about waqf is inseparable from people interest. It is due to the waqf regulations are showed as a guideline for society in implementing the waqf practices, such as: registration, management, and supervision of waqf property. In addition, the existing waqf regulations are expected to provide strong 
legal basis, particularly the existence of legal assurance to nazhir, waqif and waqf allotment. The question is, how can Nazhir manage the waqf lands?

The answer of that question is by registering the waqf land to the authority institution. Without the existing of the land waqf registration, a nazhir cannot manage the land waqf because he has not carried out waqf pledge. The land waqf registration is one of the most basic things in practicing of waqf. The waqf will not be valid if it is not registered. A nazhir will not be able to manage waqf if he has not carried out waqf land registration. Registration is opening door in implementing the management and supervision of waqf land administratively.

The land registration is conducting based on simple, safe, affordable, up-todate and open-ended principles. The principles underlying something happens and it is the basis of an activity, this is also applied on the land registration. Therefore, in the land registration there are principles that must be the basis for conducting land registration. In Article 2 of Government Regulation Number 24 of 1997 states that land registration conducted based on simple principle. The Government Regulation Number 42 Year 2006 Article 12 Paragraph 1 stated that Nazhir must administer, manage, develop, supervise, and protect the waqf property. Therefore, land waqf and religious assets are very urgent to be certified. To obtain waqf land certificate also must register the land waqf formerly. The procedures of the waqf land registration are described chronologically as follow (Nurdin, 2015: 8-9):

a. Individual/ Organization/Corporation who donate their own land (as candidate of waqif) are required to come by themselves in front of the waqf pledge certificate maker official (PPAIW) to conduct the waqf pledge.

b. Before the waqf pledging, the candidate of waqif submits the letters to PPAIW formerly. The letters are as follows:

1) Certificate or evidence sign of land ownership.

2) Statement letter from the candidate of waqif regarding the land ownership truth and it is not in the lawsuit and force filled by the Village Head and local sub-district head.

3) Land registration certificate

4) Permission letter from The Regent or The Mayor c.q. Land office of local district, it is mainly in the urban planning and master plan city context.

c. PPAIW examines the documents and its requirements whether they have fulfilled the extrication of land rights (to be donated), examined witnesses and legalized nazhir formation.

d. In front of PPAIW and two witnesses, waqif pledged or said that waqf desire to the Nazhir which had been validated. The waqf pledge was pronounced 
clearly, firmly, and appeared in written form (W.l form). Whereas for those who could not pronounce it (dumb), so they could express their desire with a gesture and then fill in the blank of W.l. If the waqif cannot meet with the official of waqf pledge certificate maker (PPAIW), so the waqif can make written pledge with the approval of Religion Ministry in the area of waqf land and then the certificate or the document is read in front of Nazhir after getting approval from the Religion Ministry. Furthermore, the signing of waqf pledge (W.l form)

e. PPAIW made the waqf pledge certificate (W.2 form) in triplicate with material according to the applicable provisions and then made copies of the waqf pledge certificate (W.2.a) in four copies. The latest one month after the waqf pledge certificate was made and each sheet sent to the BPN and others, with the distribution regulation, among others:

1) The waqf Pledge Certificate

a) The first sheet saved by PPAIW

b) The second sheet as the attachment of application letter for waqf land registration to the Waqf Office at The District (W.7)

c) The third sheet for the local Religion Court

2) The Waqf pledge certification copies

a) The first sheet for waqif

b) The second sheet for nazhir

c) The third to Local Religion Department Office

d) The fourth sheet for the local Village Head

After the procedures of waqf land registration, then waqif is considered to be administratively valid and nazhir can conduct his role in managing the waqf land. Basically, the registration of waqf land is very urgent. The urgency of waqf land registration generally provides the protection to the waqf land assets in order to maintain its existence. It means that the urgency of the waqf land registration in order to the waqf land protected by the certificate the result that there is no administrative mall or practice mall in the practicing of waqf land management. Therefore, the land which had been registered must be recorded to obtain the waqf land certificate. There are three points of urgency in waqf land registration namely normative, sociological, and juridical. 


\section{NORMATIVE URGENCY OF WAQF LAND REGISTRATION}

Normative urgency can be seen in Law which requires to conduct the assets of waqf land registration. The waqf land registration also includes the process of the waqf land certificate publishing as legal and strong evidence of waqf land. The validity of waqf certificate is very important. Minimally, by having waqf land certificate can provides ownership of a legality and legal force to the parties whose identities mentioned in the waqf land certificate. The waqf land registration and certification can prevent disputes and become strong evidence.

This situation illustrates that a certificate is interpreted as a document which is beyonD the control of the waqf land registration administration system. It means that waqf land certificate is a document or an archive of land registration authority that proves the waqf land. Due to the waqf certificate is the final result of the waqf land registration in the certificate itself contains a history of ownership of waqf land. Transferring rights process then carried out by certificate. The registration of Land deed Official (PPAT) where the waqf land registration gives a status to the owner of waqf land to a legal Nazhir and his name is listed in the certificate. Then Nazhir the owner of the waqf land certificate as the holder of ownership rights upon the waqf land. The institution that regulate and manage the land issues are carried out by the Land Office called The National Land Agency (BPN) which is established through Presidential Decree Number 26 Year 1988. The National Land Agency (BPN) has the task of carrying out measurements, and mapping and registering land in an effort to provide certainty of rights in the land sector.

From the instructions stated in the article concerning the instruction of waqf land registration, it can be seen that the purpose of waqf land registration is to provide the legal status toward the land. A legal status used as proof that waqf land has implemented and fulfilled administrative requirements so that waqf land is legally valid to be managed properly. It means that the urgency of waqf land registration has legal assurance.

Legal assurance is one of the most important that must be achieved because of it, so it will achieve the orderliness and regularity of society. The assurance itself essentially is the main goal of the law. The expectation to obtain guarantee of legal assurance of waqf land certainly must be registered indeed in accordance with the Law Number 5 of 1960 about Agrarian Principal. 
The legal assurance of waqf Pledge is a guarantee that a legal event has occurred. Among the manifestations of legal assurance is the existence documentary evidence (written evidence) in an authentic certificate. Legal assurance in the land legal is very important particularly regarding the ownership of land rights evidence. In the Article of Law number 5 of 1960 about Agrarian Principle states as follows:

1. To certify the legal assurance, land registration is carried out by the Government throughout Republic of Indonesia territory according to the provisions regulated by the Government Regulation.

2. The registration referred to the article paragraph (1), include:

a. Measuring, Mapping, and accounting land; and

b. Land rights registration and transfer. Giving the applicable certificate as the solid proof.

3. Land registration is carried out by considering the state and society conditions, socio-economic traffic requirement and the implementation possibility, according to considerations of the Agrarian Ministry

4. In the regulation of Government is regulated the costs involved with the land registration referred to paragraph (1) above, provided that poor people are freed from costs financing.

The certify of legal assurance as the normative urgency of land registration includes:

1. The assurance of right status listed

Right status is a status attached to the land. It means that by registering the waqf land, it will be able to be known the right status which is registered. Whether the satutus of the lands are Ownership Right, Business Use Right, Building Use Right, Use Right, Mortgage Right, Ownership Right on Flats or Waqf land.

2. The assurance of right subject

Through the registration of waqf, subject of the land can be known. It means that land registration will be known the holder of the right land. This is very important, either the holder of the right land is individual (Indonesian or foreigner domiciled in Indonesia), a group of people jointly hold the right land, or public legal entity .

3. The assurance of right object

Article 16 of Law Number 41 Year 2004 about Waqf states that waqf property consist of immovable and movable property. Land as the immoveable property must be clearly objected. The purpose of land includes the locations, land boundary, and land area measurement. Therefore, through land 
registration, it will be known the location, land boundary, land area measurement clearly. The certainty of object such waqf land measurement used as waqf land legality, the clarity of waqf land location also used as the effort in managing the waqf land.

\section{SOCIOLOGICAL URGENCY OF WAQF LAND REGISTRATION}

Sociological foundation illustrates that the behavior instructed in a regulation established aims to complete the society's need in various aspects. The urgency of waqf land registration shown sociologically that in order to waqf land has legal status. This aims to avoid the feasibility of conflict that will occur in the future (Supriadi, 2007: 135).

One of the issues and the implications of waqf management are arising conflict between waqf certificate with inheritance law that cannot eliminated where the process of settlement requires a deep examination. Therefore, to avoid that matter, it is necessary to control the waqf regulated in Presidential Instruction Number 1 of 1991 about Islamic Law Compilation, Law Number 41 Year 2004 about waqf, Government Regulation Number 42 Year 2006 about Waqf.

Waqf land ownership which has already regulated to publish the waqf land. However, there are people do not carry out it, such still many people who do not register their waqf land, consequently they do not have legal status which can cause conflict in the future. As in Muhammadiyah Leadership (PDM) Semarang which has already identified by researcher has not registered and certified yet. This condition be able to arise various problems in the future. For example: the owner of waqf land inheritor states that his parents do not inherit the land.

Generally, waqf property that is not registered cause the waqf land do not recorded properly and will result disputes when the waqif has passed away, because between waqif and nazhir do not have document that strengthen the position of both parties. If it occurs, then there is no authority party who act as an intermediary of clear and strong data authentic. The waqf land also often withdrawed back by inheritor who deviate from waqf pledge, Inheritors deny the waqf pledge and they do not give known by their parents. Inheritor often discuss the evidence sign both authentically and under-hand their parents (waqif) truly have already inherited their right land to Nazhir. 
This explanation strengthens that waqf land registration sociologically is very urgent. Therefore, in implementing of waqf it is not enough to rely on trust to Nazhir for managing waqf land. It also needs to carry out some procedures regarding registration and certified of waqf land. Waqf land registration also includes the publishing of waqf land certificate as a strong evidence. The strength of the use waqf land certificate enactment is very important, at least the existence of waqf land certificate provides legal entity to the owner and to the Nazhir whose name are listed in waqf land certificate. The publishing of waqf land certificate can prevent land disputes because it is protected from arbitrary action by anyone including inheritor who try to withdraw waqf land back. The giving of waqf land certificate is intended to prevent land disputes (Mustafa, 1988: 54).

The consequence toward waqf land which already certified is a land that has legal assurance and protection, it can minimize conflict that will occur against waqf land. Sociological urgency of waqf land registration also requires role of the National Land Agency (BPN) in registering waqf land based on the task that The national Land Agency of Republic Indonesia in order to cope the disputes, conflict and land case to realize land policies for justice and welfare of society. The management of assessing and handling land case is a mean to resolve the disputes, conflict and land case as well as minimize the potential of arising land cases.

\section{JURIDICAL URGENCY OF WAQF LAND REGISTRATION}

The urgency of waqf land registration juridically explains that registration of land used to supervise the existence of waqf land from prohibited practices in the Law number 41 of 2004 about waqf. According to Law Number 41 of 2004 about waqf, the properties that can be donated consist of immovable and movable properties. Land is immovable property that can be donated. Land which already donated cannot be sold or guaranteed by the parties to the other parties as regulated in Law of waqf.

In Law article 40 Number 41 of 2004 about waqf states that properties which already donated are prohibited to be guaranteed, seizure, given, endowed, or transferred in the other right transfer form. That certainty is excepted if the land which already donated is used for public interest in accordance with general spatial plan (PUPR) based on the provisions of applicable Law regulation and it is not against to Islamic law. This transformation includes the public interest with how many people can use and access the infrastructure, but it is also related to the benefits 
of infrastructure for societies welfare and progress (Muhtada \& Suhadi, 2019: 69). In addition of these expectations, waqf land may not be treated as already prohibited by the Law. The practices are the goal of urgency of waqf land registration juridically which explain that waqf land registration is shown to get supervision from related parties from prohibited practices by the law.

Supervising in waqf practice is absolute thing to do. During this time, the waqf practices in various waqf institutions by Nazhir receive less serious supervision. It results abandoned waqf land even it can cause the waqf land lost. Thus, seeing these waqf practices increasingly advance, the supervision role of waqf land cannot be ignored.

There are two forms of waqf land supervisions, namely local supervision by society and a competent government. The supervision of society carried out by waqf property council or social organization in accordance with administrative and financial feasibility standard the provisions of which are taken from applicable standard in the market. The supervision of society can be in the forms of nazhir, wakif, or community in general.

In addition, this supervision can be called more effective than supervision carried out by the government, because it is local, particularly for each waqf property regarding to people who have the rights on waqf land with its objectives directly.

Whereas, the government supervision is a form of periodic external supervision. Administratively, Government supervision of waqf land supervise waqf financial and administration by certain standard and production taken from administration supervision company that have similar activities. Financial supervision from Government also work in accordance with the principles of external supervision conducted by financial auditor and regulatory examiner. The ministry of waqf who conduct two forms of supervision both in term of financial or administrative matters to the waqf manager from private party must use a competent specialized institution and based on scientific facts from institution activities working with the market system (Hasanah, 2012: 76).

Government supervision conducted by The Ministry of Religion and Indonesian Waqf Board. The ministry of waqf which conducts these two forms of supervisions both in term of financial and administrative matters to the waqf manager from private party must use a competent specialized institution and based on scientific facts from institution's activities working with the market system.

The two forms of these supervision include both administrative and financial aspect simultaneously, either from the procedure of waqf land registration until distribution of the result from the waqf management or the allocation of waqf assets. 
Supervision of society or government aim in order to waqf land can be managed and well-developed and be able to participate in supporting societies welfare. In addition, the most important thing in supervising is prevent the prohibited practices by the Law.

The urgency of waqf land registration juridically is supervise to the waqf land assets. Waqf land supervision is regulated in Article 63 of Law number 41 of 2004 about waqf. In that Article explains that supervision of waqf management by The Ministry of Religion by involving Indonesian Waqf Board (BWI) in terms of coaching and heeding advice and considering Indonesian Ulema Council (MUI) so that the objectives and function of waqf implementation can be achieved. The Ministry of Religion by involving Indonesian Waqf Board can work together with social organizations, experts, international agencies and other parties deemed necessary for coaching to waqf management. Whereas, in the waqf management supervision, The Ministry of Religion can use public accountants.

Furthermore, in Article 65 in Law Number 41 of 2004 about waqf states that in conducting supervision, the Ministry may use public accountant. More detailed in the Article 56 of Government Regulation Number 42 Year 2006 explains that supervision of waqf land can be active or passive. Supervision carried out by the government actively by examining the Nadzir or waqf land managers at least once a year. While the passive supervisor, the Government carried out by observing on various report which conveyed by Nadzir in accordance with waqf management. In this case, societies also have rights to report on waqf management by Nazhir to the Government. The Government can apply independent public accountant services in examining of waqf land supervision. Basically, waqf land supervision requires the participation of some stockholder involved. The contribute participation not only involve certain people, but also involve poor group, such as people who follow contribution (Dani, Rodiyah, Indah, \& Waspiah, 2018: 3).

\section{CONCLUSION}

Based on the result of this research on the urgency of waqf land registration in Law Perspective Number 4l Year 2004 about waqf by the Regional Leadership of Muhammadiyah Semarang, from the result and the explanation of research can be concluded as follows:

1. Normative urgency of waqf land registration gives legal assurance. Legal assurance used to understand the certainty of right list includes right changes, 
right subject which include landowner and right object which include the location and wide land. Subject certainty of land will determine the content of waqf pledge certificate and waqf land certificate.

2. Sociological urgency of waqf land registration used in order to waqf land has legal status. It aims to prevent disputes feasibility that will occur in the future. One of issues and the implications of waqf management that often arise is the existence of conflict against waqf certificate with inherit law which cannot be lost which the process of settlement requires deep examination. Therefore, to avoid that matter needs to conduct the publishing of waqf land that is regulated in Presidential Instruction Number 1 about waqf, Government Regulation Number 42 Year 2006 about waqf.

3. Juridical urgency of waqf land registration states that juridically land registration used to supervise the existence of land from prohibited practices in Law Number 41 Year 2004 about waqf, that properties which already donated consist of immovable and movable properties. Land is immovable property that can be donated. The land which already donated may not be sold or guaranteed by anyone to the other parties which is regulated in Law of waqf land.

\section{SUGGESTION}

Related to the research conducted, Author provides suggestions to be used as input and consideration matter that are useful for interested parties, among others:

1. A nazhir should conduct his duty in managing waqf administration, include the most important thing is to register waqf land to the authority institution, thus waqf land has legal entity.

2. A waqif, someone who donate his properties to be donated for religion need and public welfare. As a state of law, any legal action must agree with Law. Therefore, waqif needs to learn more about waqf procedures.

\section{REFERENCES}

Ashshofa, B. (2010). Metode Penelitian Hukum. Jakarta: Rineka Cipta

Harsono, B. (2008). Hukum Agraria Indonesia. Jakarta: Djambatan

Hasanah, U. (2012). Urgensi Pengawasan dalam Pengelolaan Wakaf Produktif. AlAhkam 22(1), 67-82. 
Hasmi, S.A. (1987). Management of Waqf: Past and Present in Management and Development of Awqaf Properties. Proceeding of The Seminar, Jeddah: Islamic Research and Training Institute, Islamic Development Bank

Kemenag. siwak.kemenag.go.id

Muhtada, D., \& Suhadi, S. (2019). Transformation of the Meaning of Public Interest in the Indonesian Regulations on Land Acquisition: A Sustainable Development Perspective. Advances in Social Science, Education and Humanities Research 358, Atlantis Press.

Mustafa, B. (1988). Hukum Agraria Dalam Perspektif. Bandung: Remaja Karya

Nurdin, N. (2017). Tata cara Pencatatan harta Benda Wakaf (Petunjuk Teknis Bagi Nadzir Wakaf). Retrieved from www.sumsel.kemenag.go.id (21 January 2020).

Rachman, M. (1993). Strategi dan Langkah-Langkah Penelitian. Semarang: IKIP Semarang Press.

Republic of Indonesia. Islamic Law Compilation, Kompilasi Hukum Islam (KHI).

Republic of Indonesia. (2006). Peraturan Pemerintah No 42 Tentang Pelaksanaan Undang-Undang Nomor 41 Tahun 2006 Tentang Wakaf

Republic of Indonesia. (2004). Undang-Undang Nomor 41 Tahun 2004 Tentang Wakaf

Republic of Indonesia. (1981). Undang-Undang Nomor 8 Tahun 1981

Rodiyah, R., Muhtada, D., Utari, I.S., \& Waspiah, W. (2018). Village Bureaucracy Reform in Democracy and Autonomy Era in Indonesia: Study of The Establishment of Laws and Regulations Method by IRR Model. South East Asia Journal of Contemporary Business, Economics and Law, 17(4), (December) ISSN 22891560

Sumardjono, M.S.W. (2001). Kebijakan Pertanahan Antara Regulasi \& Implementasi. Jakarta: Kompas

Supriadi, S. (2007). Hukum Agraria. Jakarta: Sinar Grafika

Wignjosoebroto, S. (2009). Ragam-Ragam Penelitian Hukum. in Sulistyowati Irianto \& Shidarta. (Eds). Metode Penelitian Hukum: Konstelasi dan Refleksi. Jakarta: Yayasan Obor Indonesia. 